\title{
Interactions between Mutations Affecting Ribosome Synthesis in Escherichia coli
}

\author{
By PETER D. BUtLER, EMILIO CATTANEO and DONALD G. Wild* \\ Microbiology Unit, Department of Biochemistry, University of Oxford, South Parks Road, \\ Oxford OXI $3 Q U, U K$
}

(Received 21 September 1984)

RNA synthesis was followed during amino acid starvation of strains of Escherichia coli that contained both the relaxed ( relA) mutation and a mutation affecting ribosome assembly that results in oversynthesis of RNA. The ribosome mutation did not by itself lead to relaxedness. The relaxed mutation could be expressed in organisms that contained the ribosome mutation.

\section{INTRODUCTION}

In exponentially growing Escherichia coli, the number of ribosomes per unit protein is proportional to growth rate over a wide range of conditions (Gausing, 1980). Ribosome assembly thus requires not only the coordinated synthesis of the fifty or so ribosomal proteins and three ribosomal RNAs but mechanisms that vary rates of synthesis in response to the external milieu. Some of the devices used have been described. Ribosomal protein genes are organized into transcription units that code for from one to eleven proteins. Synthesis from at least some units is regulated by binding of excess of a key ribosomal protein to the $5^{\prime}$ leader region of its mRNA so as to inhibit translation (or attenuate transcription) of the proteins of the unit (Lindahl \& Zengel, 1982; Lindahl et al., 1983). If this mechanism is general, rates of ribosomal protein synthesis will respond to altered rates of synthesis of the ribosomal RNAs to which the key proteins bind preferentially. Thus mechanisms that affect control of rRNA synthesis may be the more immediate. One suggestion (Jinks-Robertson et al., 1983) is that nontranslating ribosomes feed back on synthesis with the consequence that bacteria contain the minimum number of ribosomes required to sustain a given growth rate. This idea is consistent with the oversynthesis of ribosomal RNA by some mutants with defects in ribosome assembly that result in low numbers of free sub-units being present. A further extension of the hypothesis encompasses the 'stringent' response in which organisms abruptly deprived of an amino acid stop synthesis from rRNA cistrons while mutants 'relaxed' in this control system continue to make RNA when a required amino acid is withdrawn. However, stringency has associated with it the synthesis of the nucleotide ppGpp by an 'idling' step on ribosomes during amino acid starvation. The nucleotide interacts with RNA polymerase to inhibit transcription from 'stringent promoters' (Gallant, 1979). It is thus not clear to what extent the stringent response is concerned with the feedback loop involving free ribosomes.

A strain of $E$. coli that overproduces RNA during exponential growth is the mutant TP28, derived from E. coli 15 thy pro (E. coli 15TP) (MacDonald et al., 1967). A mutation in TP28 at about $82 \mathrm{~min}$ on the genetic map halves the rates of synthesis of ribosomal proteins L28 and L33 from the rpmB,G transcription unit (Butler \& Wild, 1984, 1985). In a given medium, the mutant grows at about half the rate of its parent but mutant cells contain about $60 \%$ more RNA per unit protein. Much of this excess RNA (and about half the 23S rRNA of the organisms) is in "47S particles'. These are unusual precursors to 50S ribosomal sub-units that lack L28 and L33 and are deficient in some other ribosomal proteins (Markey et al., 1976; Butler \& Wild, 1984). The missing proteins add in a final abnormal step to give sub-units that are incorporated into $70 \mathrm{~S}$ 
ribosomes. The latter have a full complement of proteins but work rather poorly in protein synthesis (Butler et al., 1978).

The experiments below describe the response to amino acid starvation of organisms that contain both the ribosome mutation of strain TP28 and the 'classic' relaxed (relA) mutation which maps at about $60 \mathrm{~min}$. The ribosome mutation does not by itself lead to relaxedness. The relaxed mutation can be expressed in organisms that contain the ribosome mutation.

\section{METHODS}

The strains used were (i) E. coli 15 thy pro and the mutant 15-28 (TP28) derived from it, (ii) the K12 strain RE74 (relA, pyrE, metB), and (iii) three transductants of strain RE74 obtained using bacteriophage P1 cam clr100 induced in lysogens of strain TP28 (Butler \& Wild, 1985) as the vector. In two of these transductants (RE74-807 and RE74-825), pyrE $E^{+}$and the (linked) ribosome mutation have been transferred from TP28, while in the third, RE74-803, pyrE $E^{+}$, but not the ribosome mutation, is present. Organisms were grown at $37^{\circ} \mathrm{C}$ with shaking in a Tris-based minimal medium (Blundell \& Wild, 1969) with glucose $(0.2 \%)$ as carbon source and supplemented as required with thymine $\left(10 \mu \mathrm{g} \mathrm{ml}^{-1}\right)$, proline $\left(50 \mu \mathrm{g} \mathrm{ml}^{-1}\right)$, methionine $\left(50 \mu \mathrm{g} \mathrm{ml}^{-1}\right)$ and uracil $\left(10 \mu \mathrm{g} \mathrm{ml}^{-1}\right)$. To follow RNA synthesis, $\left[{ }^{14} \mathrm{C}\right]$ uracil $\left[0.04 \mu \mathrm{Ci}(1.48 \mathrm{kBq}, 20 \mu \mathrm{g}) \mathrm{ml}^{-1}\right]$ was included in the medium and samples $(0.5 \mathrm{ml})$ were taken at intervals for the estimation of radioactivity insoluble at $0{ }^{\circ} \mathrm{C}$ in $5 \%(\mathrm{w} / \mathrm{v})$ trichloroacetic acid (Markey \& Wild, 1976). Filtration, at $\mathrm{OD}_{450} \sim 0.4$ and after about three generations of exponential growth, was through Oxoid $5 \mathrm{~cm}$ membrane filters: organisms were washed on the filter with 2 vols prewarmed medium and resuspended in the same volume of medium with or without a required amino acid or containing chloramphenicol $\left(50 \mu \mathrm{g} \mathrm{ml}^{-1}\right)$.

For the preparation of extracts, organisms from $40 \mathrm{ml}$ culture were harvested, washed and resuspended in $2 \mathrm{ml}$ THMK buffer (10 mM-Tris/HCl, pH 7·4, $10 \mathrm{mM}$-magnesium acetate, $100 \mathrm{mM}-\mathrm{KCl})$ and broken in a French pressure cell. Portions $(150 \mu \mathrm{l})$ of extract were centrifuged at $4{ }^{\circ} \mathrm{C}$ through $15-30 \%$ sucrose gradients in THMKSp buffer (THMK buffer plus $1 \mathrm{mM}$-spermidine. $\mathrm{HCl}$ ) using a Spinco SW 50.1 rotor. Gradients were pumped through an Isco density gradient fractionator and collected as about 50 3-drop fractions that were subsequently assayed for radioactivity (Markey \& Wild, 1976).

\section{RESULTS AND DISCUSSION}

RNA synthesis by the various strains was followed after a required amino acid was withdrawn. There was no significant net synthesis of RNA during proline starvation of the mutant TP28 (or its parent, strain 15TP) (Fig. 1a). Strain RE74 was relaxed and so was strain RE74-803, which had acquired the $p y r E^{+}$locus, but not the ribosome mutation, from strain TP28. This transductant had a generation time (about $80 \mathrm{~min}$ ) similar to that of strain RE74. When methionine-starved, strain RE74-803 at first made RNA at the same rate as a growing culture; the rate declined after about $40 \mathrm{~min}$ of starvation (Fig. 1b). Transductants RE74-807 and RE74-825 had acquired the ribosome mutation of strain TP28 as well as the $p y r E^{+}$locus. Both these organisms synthesized RNA extensively during methionine starvation (Fig. $1 c, d$ ). The increases in RNA content in the first $90 \mathrm{~min}$ of starvation (equivalent to about half a generation time) were $95 \%(\mathrm{RE74-807)}$ and $70 \%$ (RE74-825) of those in growing control cultures. The three transductants were also grown with $\left[{ }^{14} \mathrm{C}\right]$ uracil present and then the RNA made during starvation was labelled with $\left[{ }^{3} \mathrm{H}\right]$ uracil. Extracts made after starvation were sedimented through sucrose gradients. With strain RE74-803, the centrifuging generated a 'normal' ${ }^{14} \mathrm{C}$-labelled sedimentation profile with $70 \mathrm{~S}$ ribosomes as the major component (Fig. $2 a$ ). Strain RE74-807 (and RE74-825; results not shown) gave a profile very similar to that of strain TP28 with large quantities of $47 \mathrm{~S}$ particles present relative to $70 \mathrm{~S}$ ribosomes (Fig. $2 b$ ). The sedimentation profiles show that much of the $\left[{ }^{3} \mathrm{H}\right] \mathrm{RNA}$ synthesized during starvation of transductant RE74-803 was in two components located on either side of the 30S sub-units. These sedimentation characteristics are similar to those of 'relaxed particles' that contain precursor forms of ribosomal RNA and are synthesized by other relaxed strains during amino acid starvation (Sykes et al., 1977). Most of the RNA made during starvation of transductant RE74807 (and transductant RE74-825) was in particles with very similar sedimentation properties, although in rather different proportions. A few $47 \mathrm{~S}$ particles (or precursor to them: Butler et al., 1980) were also apparently synthesized (Fig. 2b). As shown in Fig. $1(a)$, strain TP28 makes little RNA during proline starvation. However, synthesis of RNA and protein by this mutant could 


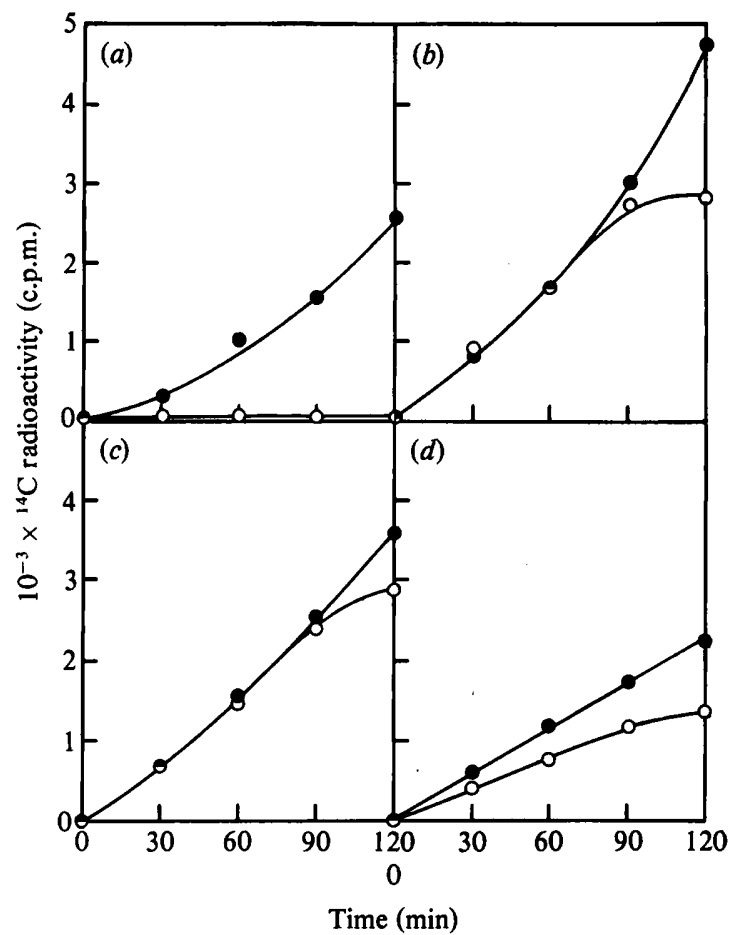

Fig. 1. RNA synthesis during amino acid starvation of (a) strain TP28, (b) transductant RE74-803, (c) transductant RE74-807, and (d) transductant RE74-825. Procedures are described in the text.

, Unstarved control; $\bigcirc$, starved culture.

be uncoupled by chloramphenicol. As with other strains of $E$. coli, the antibiotic inhibited protein synthesis but allowed RNA synthesis to continue. The 'chloramphenicol particles' that accumulated (Fig. 2c) had sedimentation coefficients very similar to those of the particles formed during amino acid starvation. (The status of chloramphenicol particles and relaxed particles as intermediates in normal pathways of ribosome assembly is arguable, and is discussed by Sykes et al., 1977.)

The results thus show that the mutant TP28 makes very little, if any, RNA during proline starvation and so is stringent. But, since this strain already has almost twice the RNA content of its parent, it is already in this sense 'relaxed' and for this reason might be unable to respond further to amino acid starvation. However, chloramphenicol can uncouple RNA and protein synthesis in strain TP28 which is in these circumstances able to increase its RNA content further. Moreover, the synthesis of RNA during methionine starvation of transductants RE74807 and RE74-825 shows that the relaxed mutation can be expressed in the presence of the ribosome mutation, with consequences similar to those in other strains and during chloramphenicol inhibition.

As in strain TP28 itself, the 47S particles of transductant RE74-807 contain, per particle, $5 \%$ at most of the L28 and L33 in a 70S ribosome (Butler \& Wild, 1985). Thus the concentration of free $50 \mathrm{~S}$ sub-units (which will be included with the $47 \mathrm{~S}$ particles when the latter are analysed) must be very low. This situation may result in constant oversynthesis of RNA by TP28 and derivatives as suggested by Jinks-Robertson et al. (1983). However, if this is so, this oversynthesis is functionally (and genetically) distinct from the relA mutation. An economic explanation is that the response of organisms to the abrupt withdrawal of an amino acid is mediated by mechanisms largely independent of the systems used to regulate ribosome assembly at different growth rates. In some transcription units, these mechanisms may eventually interact at promoter sites since ppGpp has been found to reduce synthesis from only one of the pair of 


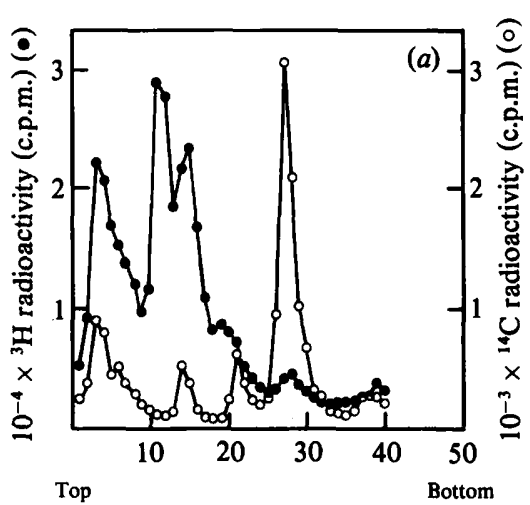

Fraction no.

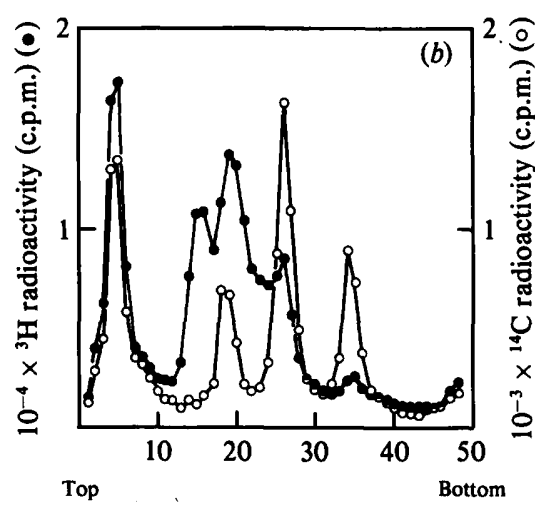

Fraction no.

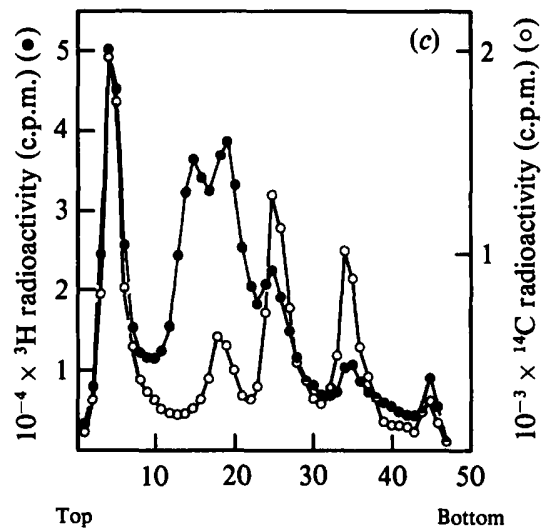

Fraction no.

Fig. 2. Sedimentation profiles of strain TP28 and transductants. (a) Transductant RE74-803 was grown in medium containing $\left[{ }^{14} \mathrm{C}\right]$ uracil $\left[0.02 \mu \mathrm{Ci}(10 \mu \mathrm{g}) \mathrm{ml}^{-1}\right]$ from $\mathrm{OD}_{450} 0.05$ to 0.4 . A portion $(40 \mathrm{ml})$ was filtered, washed and resuspended in $40 \mathrm{ml}$ medium containing [ $\left.{ }^{3} \mathrm{H}\right] \mathrm{uracil}\left[2.5 \mu \mathrm{Ci}(92.5 \mathrm{kBq}, 5 \mu \mathrm{g}) \mathrm{ml}^{-1}\right]$ but lacking methionine. After $30 \mathrm{~min}$, organisms were collected, and an extract was made and centrifuged. (b) The procedure, with transductant RE74-807, was similar but starvation was for $60 \mathrm{~min}$. (c) Strain TP28 was grown to $\mathrm{OD}_{450} 0.4$ with $\left[{ }^{14} \mathrm{C}\right] \mathrm{uracil}\left[0.05 \mu \mathrm{Ci}(10 \mu \mathrm{g}) \mathrm{ml}^{-1}\right]$ present. Organisms were filtered and resuspended for $30 \mathrm{~min}$ in the same volume of fresh medium containing chloramphenicol $\left(50 \mu \mathrm{g} \mathrm{ml}^{-1}\right)$ and $\left[{ }^{3} \mathrm{H}\right] \mathrm{uracil}\left[5 \mu \mathrm{Ci}(5 \mu \mathrm{g}) \mathrm{ml}^{-1}\right]$.

tandem promoters in the $r r n A$ and $r r n E$ units, perhaps by destabilizing the polymerase-promoter complex (Glaser et al., 1983; Kajitani \& Ishihama, 1984). There are multiple promoters for at least one ribosomal protein operon (protein S1) where similar effects of ppGpp have been noted (Kajitani \& Ishihama, 1984) and similar considerations may therefore apply.

This work was supported by the Medical Research Council.

\section{REFERENCES}

BLUNDELL, M. R. \& WILD, D. G. (1969). Inhibition of bacterial growth by metal salts. The accumulation of ribonucleic acid during inhibition of Escherichia coli by cobalt chloride. Biochemical Journal 115, 213-223.

Butler, P. D. \& Wild, D. G. (1984). Ribosomal protein synthesis by a mutant of Escherichia coli. European Journal of Biochemistry 144, 649-654.

ButLeR, P. D. \& WiLD, D. G. (1985). The location of a mutation affecting ribosomal protein synthesis by Escherichia coli. Journal of General Microbiology 131, 135-144.
Butler, P. D., Sims, P. F. G. \& Wild, D. G. (1978). Binding of chloramphenicol and a fragment of aminoacyl-transfer ribonucleic acid to ribosomes and a ribosome precursor from a mutant of Escherichia coli. Biochemical Journal 172, 503-508.

Butler, P. D., Sims, P. F. G. \& Wild, D. G. (1980). Intermediates in the assembly of ribosomes by a mutant of Escherichia coli. Biochemical Journal 190, 157-170.

Gallant, J. A. (1979). Stringent control in E. coli. Annual Review of Genetics 13, 393-415. 
Gausing, K. (1980). Regulation of ribosome biosynthesis in E. coli. In Ribosomes: Structure, Function and Genetics, pp. 693-718. Edited by G. Chambliss, G. R. Craven, J. Davies, K. Davis, L. Kahan \& M. Nomura. Baltimore: University Park Press.

Glaser, G., Sarmientos, P. \& Cashel, M. (1983). Functional interrelationship between two tandem $E$. coli ribosomal RNA promoters. Nature, London 302, 74-76.

Jinks-Robertson, S., Gourse, R. L. \& Nomura, M. (1983). Expression of rRNA and tRNA genes in Escherichia coli: evidence for feedback regulation by products of rRNA operons. Cell 33, 865-876.

Kajitani, M. \& Ishihama, A. (1984). Promoter selectivity of Escherichia coli RNA polymerase. Differential stringent control of the multiple promoters from ribosomal RNA and protein operons. Journal of Biological Chemistry 259, 1951-1957.

LINDAHL, L. \& ZENGEL, J. M. (1982). Expression of ribosomal genes in bacteria. Advances in Genetics 21, 53-121.
Lindahl, L., ARcher, R. \& Zengel, J. M. (1983). Transcription of the $S 10$ ribosomal protein operon is regulated by an attenuator in the leader. Cell 33, 241248.

MacDonald, R. E., Turnock, G. \& ForchHammer, J. (1967). The synthesis and function of ribosomes in a new mutant of Escherichia coli. Proceedings of the National Academy of Sciences of the United States of America 57, 141-147.

MARKEY, F. \& WILD, D. G. (1976). An unusual precursor of $50 \mathrm{~S}$ ribosomes in a mutant of Escherichia coli. Biochemical Journal 154, 311-318.

MARKeY, F., Sims, P. F. G. \& WiLd, D. G. (1976). The composition of an unusual precursor of $50 \mathrm{~S}$ ribosomes in a mutant of Escherichia coli. Biochemical Journal 158, 451-456.

Sykes, J., MetCalf, E. \& PiCkering, J. D. (1977). The nature of the proteins present in the relaxed particles' from methionine-starved Escherichia coli A 19 (Hfr rel met rns). Journal of General Microbiology 98, 17-27. 